\title{
Software Quality Requirement Analysis on Educational Mobile Game with Tourism Theme
}

\author{
Anggy Trisnadoli*, Istianah Muslim, Wenda Novayani \\ Computer Department, Politeknik Caltex Riau, Pekanbaru, Indonesia. \\ * Corresponding author. Tel.: +62 85265815640 ; email: anggy@pcr.ac.id \\ Manuscript submitted March 10, 2016; accepted May 11, 2016. \\ doi: 10.17706/jsw.11.12.1250-1257
}

\begin{abstract}
Mobile game is one type of game that runs on mobile devices such as smartphones and tablet PCs. In previous research, we have proposed quality model for mobile game which is a quality model that was built to measure quality from mobile games. This model was built from quality requirements that were analyzed for mobile games. Educational mobile game is education game genre with mobile based that aimed to learning, then the quality requirements maybe will different compared to other games. This research was conducted by analyzing the mobile game's quality requirements that specific for educational games genre in order to generate new quality requirements that are specific to the mobile educational game. The case studies that become an evaluation of current research are the tourism of Riau province, Indonesia. So the mobile educational game that will design later is a mobile educational game that contains about tourism in Riau province. To get a list of criteria for this case, then we conducted a survey of several users, and also formed a group discussion forum along with a tourism ambassador of Riau province, so that the quality requirements will be more reliable. So the proposed quality requirements may become a reference to build a game product that has a good quality based on the user's perspective.
\end{abstract}

Keywords: Software quality, games, mobile games, educational mobile games, tourism, riau province.

\section{Introduction}

Game is a system composed of artificial rules that involve players with the aim to entertain [1], [2]. Game contains scenarios that composed of a collection of audio and visual interest that allows users to enjoy game play that has been given by the game. By the unique characteristics game compared to other software, then, there are many things that do more specific, special for the games. Quality model for mobile game is one of the quality models that were built to measure the quality of the mobile games [3]. This model was built based play ability quality models built by Sánchez et al [4] and adapted to the quality requirements for mobile games [3]. In its application this quality model used to measure the quality of a user's perspective, so that measurements can be made after the game finished mobile products developed.

In designing an educational game, it must be guided by a good reference. Quality assurance can be done starting of the development stage, the design stage. Quality models for the mobile game offers a collection of properties that indicate the needs of a mobile game quality, so that the quality requirements can be used as a reference in building a good mobile game. However, that offered quality requirement is built for the mobile game in general, while the mobile educational game is a genre the mobile game with educational or learning, so that the quality requirements could have a few differences. Based on these problems, so, in this research we performed an analysis of the mobile game's quality requirements that are specific to the 
educational games genre, to be able to produce a game product that has fit quality of the quality requirements based on the user's perspective.

As for the issues that will be studied in this paper are does requirements for a quality mobile game can be used as a reference in the design stage of development the mobile educational games. And how far the relationship of quality requirements for mobile game required to Mobile Educational Games with Tourism content of the user's perspective to be able produce a good quality product.

\section{Analysis of Quality Requirements for Mobile Games and Educational Games}

\subsection{Quality Requirement for Mobile Game}

In 2015, research on the quality model for mobile games has been conducted by Trisnadoli, Hendradjaya and Sunindyo [2] entitled 'A Proposal Quality Model for Mobile Games'. Quality Model for Mobile Game was formed based on the software quality requirements that has been compiled based on the criteria and ideas from several researches on mobile games [3]. The proposed model has quality factors as shown on Fig. 1.

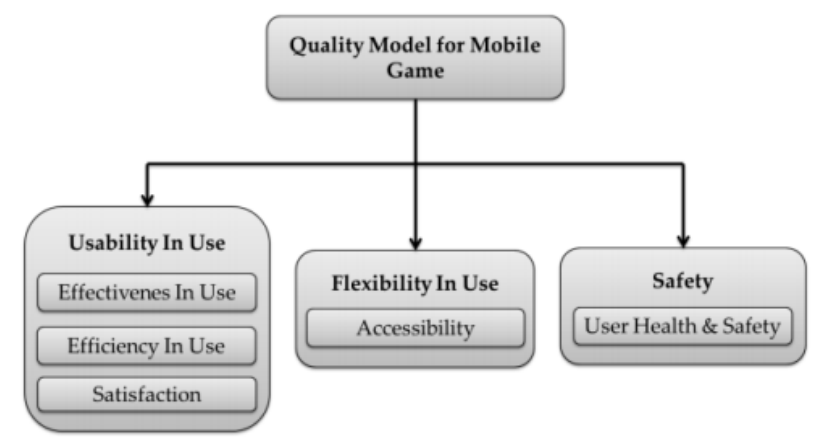

Fig. 1. Quality Model for Mobile Games [2].

Factors and sub factors for the quality of the quality model for mobile games that have been proposed are Usability In Use with sub factors Effectiveness In Use, Efficiency In Use, Satisfaction. Then Flexibility In Use with sub factor Accessibility. And Safety with subfactor User Health \& Safety.

Table 1. Quality Requirements for Mobile Games [3]

\begin{tabular}{ll}
\hline \hline No & Quality Requirements for Mobile Games \\
\hline $\mathbf{1}$ & Game gives a clear goal and a player can achieve goal \\
$\mathbf{3}$ & Players do not find any error in the game \\
$\mathbf{4}$ & Game can be played in a short time \\
$\mathbf{5}$ & Game easy to understand by players \\
$\mathbf{6}$ & Game has a manual (help feature) \\
$\mathbf{7}$ & Gontrol of the game has been consistently in according with the standards \\
$\mathbf{8}$ & Challenges, strategies and the steps of the game are already balanced \\
$\mathbf{9}$ & Screen layout is comfortable to be seen \\
$\mathbf{1 0}$ & Audio of the game was comfortable and supportive with a good game \\
$\mathbf{1 1}$ & Mobile devices and game interface are already suitable and appropriate \\
$\mathbf{1 2}$ & The experience of playing is Fun \\
$\mathbf{1 3}$ & Players get the appropriate reward \\
$\mathbf{1 4}$ & Storyline or scenario of the game is interesting \\
$\mathbf{1 5}$ & Players can express themselves \\
$\mathbf{1 6}$ & No repetition that make the game boring \\
$\mathbf{1 7}$ & Game control is appropriate and flexible
\end{tabular}


Mobile game is defined as a game played on a mobile platform-based devices are expected to increase the entertainment on the user's mobile device. Mobile devices that can be applied to mobile game such as Smartphones, PDAs, Tablet PCs and Portable Game Console. Mobile game is highly dependent on the device that became his home [5]. Based on the characteristics of mobile games and mobile applications presented by several researchers [6]-[11] then performed an analysis of the characteristics and then were extracted to produce set of quality requirements are been the foundation of building a quality requirement that will be used. After conducting an analysis of data that has been collected, so, the conclusion of proposed quality requirements for mobile game can be seen in Table I.

\subsection{Educational Game Genre Characteristics}

According to Sugihartono [12], educating means the process of changing the attitudes and behavior of a person or group with a mature effort with teaching and training efforts. Education can be obtained for both formal and informal. Formal education was obtained from a structured learning that has been designed by an institution. While the non-formal education is the knowledge gained humans in everyday life either experienced or learned from others. One way to learn with non-formal system is by educational game.

Educational games are games that are designed or created to stimulate thought include improving concentration and problem-solving [13]. YM Harahap on [14] concluded that the educational game is one of the games that can be useful to support the teaching and learning process with more fun and more creative, and usable to provide teaching or increase user knowledge by an exciting media. According to Hurd and Jennings [15] declared that educational game is game that is specifically designed to teach user a certain learning, concept development and understanding and guide them in their ability to train and motivate them to play. Factors that are considered necessary in developing educational game are usability, accuracy, appropriateness, Relevance, Objectiveness, Feedback, Engagement, Motivation, and Gaming Literacy.

Dondlinger [16], said that a number of distinct design elements on educational games are narrative context, rules, goals, rewards, multisensory cues, and interactivity seem necessary to stimulate desired learning outcomes. And a few other things about the characteristics of the educational game are Challenging, Fun, and Excitement not patronizing and based on experience, interactive, expertise, reflection.

\section{Designing the Quality Requirements for Educational Mobile Games}

Determination of the quality requirements of mobile educational games, we perform an analysis based on various sources of quality requirements, such as the quality requirements that have been offered by previous researchers then combine from survey results that conducted on some respondents, while also using the functional requirements of mobile educational game stakeholders for tourism in Riau province. So that, the proposed quality requirements can become a reference in developing mobile educational game with good quality.

\subsection{Quality Requirements for Mobile Educational Game Based on User's Perspective}

In determining the quality requirements of mobile games from the user's perspective, data collection or surveys conducted to several respondents randomly. Respondents, who being questioned are derived from various professions, age, sex, and excitement in playing the games. The stuff to consider in conducting a survey on software quality requirements analysis for mobile games are The comfort of audio and visual, Interest on the storyline, Satisfaction in playing, the comfort using control game, Screen size of mobile 
devices, Addictive (the desire to repeat the game).

Survey of users was conducted in the form of an interview. Selection of respondents by random sampling method is applied to 130 people with different backgrounds, but still has an interest in using games on mobile devices.

The interview results are then analyzed and processed by concluding and verification of data obtained. Table 2 is the result of the conclusions of the quality requirements of mobile games based on the user's perspective.

Table 2. Survey Result on Requirements from User's Perspective

\begin{tabular}{|c|c|c|}
\hline No & Indicator & Requirements \\
\hline 1 & $\begin{array}{l}\text { The comfort of } \\
\text { audio and visual }\end{array}$ & $\begin{array}{l}\text { Mobile game should be good appearance } \\
\text { The layout that is used comfortably viewed } \\
\text { Color usage harmonious and good }\end{array}$ \\
\hline 2. & Game Controller & $\begin{array}{l}\text { The buttons position is appropriate } \\
\text { The controller usage is simple }\end{array}$ \\
\hline 3 & Storyline & $\begin{array}{l}\text { Game characters are Interesting } \\
\text { Scenario of the games are not boring } \\
\text { The desire to repeat the game again and again }\end{array}$ \\
\hline
\end{tabular}

Based on data that shown in Table II, and after calculation of the number of respondents who give a positive statement on the list of requirements, so the number was created in the percentage as shown in Fig. 2.

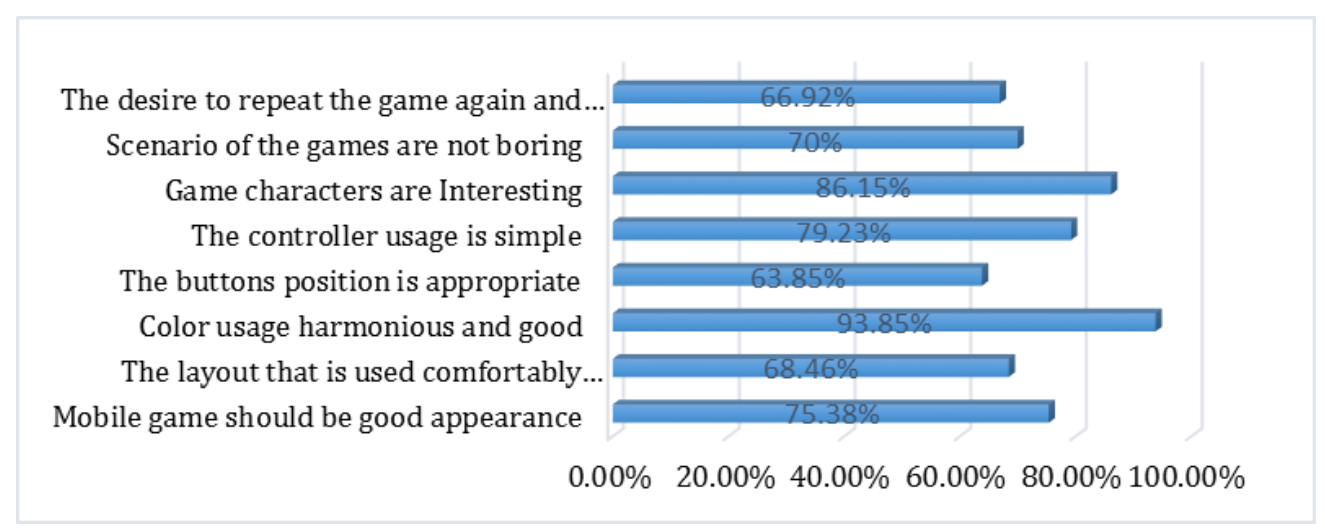

Fig. 2. Survei result on requirements from user's perspective by percentage.

\subsection{The Results of the Forum Group Discussion for Riau Province Tourism Case Study}

Forum Group Discussion (FGD) was conducted to get a conclusion for the criteria that are required to build a mobile educational game with a case study of tourism on Riau province. This activity was attended by 35 participants that were an ambassador for tourism in Riau province. Discussions were held during few hours, then, closed with some results which can be seen in Table 3.

From the discussion we get conclude that the most important content in game tourism theme are Arts, Tourist Attraction and Folklore. Arts with Traditional Dance, Songs and Musical Instrument. Tourist Attraction with Nature and Historical Heritage. Folklore with Legend and Fairy Tales. Table III shows the various technical criteria to be considered in the development of an interesting mobile educational game. In order to build a mobile educational game on tourism sector, there are several things to consider such as the content, simple but meaningful and interesting, and don't forget to contain about Malay art and culture, because it is a hallmark from Riau Province. As for the interface of this educational game, the things to consider are the attractive appearance, the use of color that comfortable to look at and pleasant sound to be 
heard.

After discovering the things that become important considerations in the requirement of mobile games, educational games, also the requirement for mobile game with tourism content, then formed a new calculation to show the overlapping and interrelated requirements to be good quality requirements as a reference in designing a mobile-based game with education genre and tourism case study in Riau province. The results of the analysis are shown in Table 4.

Table 3. FGD Result to Mobile Educational Game Criteria

\begin{tabular}{lll}
\hline \hline \multicolumn{1}{c}{ No } & \multicolumn{1}{c}{ Indicators } & \multicolumn{1}{c}{ Criterias } \\
\hline $\mathbf{1}$ & Interface & Attractive appearance (eye catchy) \\
$\mathbf{2}$ & The color usage is comfortably viewed \\
$\mathbf{3}$ & Audio & comfortable to hear \\
$\mathbf{4}$ & & Interesting storyline or game play \\
$\mathbf{5}$ & Storyline & Not boring \\
$\mathbf{6}$ & & Addiction (wanted to play again-and \\
& & again) \\
$\mathbf{7}$ & Education Contents & Simple but meaningful \\
& & Growing a curiosity \\
\hline \hline
\end{tabular}

Table 4. Mapping of Quality Requirements for Mobile Educational Games with Tourism Theme

\begin{tabular}{|c|c|c|c|c|}
\hline Requirements & $\begin{array}{c}\text { Quality } \\
\text { Requirements } \\
\text { for Mobile } \\
\text { Games [3] }\end{array}$ & $\begin{array}{c}\text { Previous } \\
\text { Research on } \\
\text { Educational } \\
\text { Game }\end{array}$ & $\begin{array}{c}\text { Survey } \\
\text { Result from } \\
\text { User's } \\
\text { Perspective }\end{array}$ & $\begin{array}{c}\text { FGD } \\
\text { Result on } \\
\text { Educatio } \\
\text { nal Game } \\
\text { on } \\
\text { Tourism } \\
\end{array}$ \\
\hline Game provides a clear goals & $\sqrt{ }$ & $\sqrt{ }$ & $\sqrt{ }$ & \\
\hline Game is easy to understand & $\sqrt{ }$ & $\sqrt{ }$ & $\sqrt{ }$ & $\sqrt{ }$ \\
\hline Game can be played in a short time & $\sqrt{ }$ & & $\sqrt{ }$ & \\
\hline Game have complete features & $\sqrt{ }$ & & $\sqrt{ }$ & \\
\hline $\begin{array}{l}\text { Control of the game has been consistently in according with } \\
\text { the standards }\end{array}$ & $\sqrt{ }$ & $\sqrt{ }$ & $\sqrt{ }$ & \\
\hline Screen layout is comfortable to be seen & $\sqrt{ }$ & $\sqrt{ }$ & $\sqrt{ }$ & $\sqrt{ }$ \\
\hline $\begin{array}{l}\text { Audio of the game was comfortable and supportive with a } \\
\text { good game }\end{array}$ & $\sqrt{ }$ & $\sqrt{ }$ & $\sqrt{ }$ & $\sqrt{ }$ \\
\hline The mobile device screen is appropriate to the game & $\sqrt{ }$ & & $\sqrt{ }$ & \\
\hline The experience of playing is Fun & $\sqrt{ }$ & $\sqrt{ }$ & $\sqrt{ }$ & $\sqrt{ }$ \\
\hline Storyline or scenario of the game is interesting & $\sqrt{ }$ & $\sqrt{ }$ & $\sqrt{ }$ & $\sqrt{ }$ \\
\hline No repetition that make the game boring & $\sqrt{ }$ & $\sqrt{ }$ & $\sqrt{ }$ & $\sqrt{ }$ \\
\hline Game control is appropriate and flexible & $\sqrt{ }$ & & & $\sqrt{ }$ \\
\hline Players gain knowledge from the game & & $\sqrt{ }$ & & $\sqrt{ }$ \\
\hline Game is simple but meaningful & & & $\sqrt{ }$ & $\sqrt{ }$ \\
\hline Content on tourism must be update & & & & $\sqrt{ }$ \\
\hline Language usage appropriate to target of player & & $\sqrt{ }$ & $\sqrt{ }$ & $\sqrt{ }$ \\
\hline Having educate messages behind the entertainment given & & $\sqrt{ }$ & & $\sqrt{ }$ \\
\hline
\end{tabular}

Based on that Table 4, indicated that some requirements are actually owned by all sources are used, but there are some requirements that are not discussed on several sources. Especially the contents of tourism that it only required if the specific case study towards the tourism sector, would be an important thing for the preparation of quality requirements.

\section{The Proposed Quality Requirements for Mobile Education Game with the Tourism Theme}

Based on all the stages that have been done before, and then we analyze it to propose a new quality 
requirement. Proposed quality requirements for mobile educational game that specific to tourism case study are show on Table V. It contains the proposed quality requirements for mobile educational game with a case study of tourism. So in designing and developing mobile educational game later, these quality requirements can become one of factor to be good quality software. Because of the good quality software is start from the design stage, not only during the implementation or development, even when they are published to the user.

Table 5. Proposed Quality Requirements for Mobile Educational Games with Tourism Case Study

\begin{tabular}{cl}
\hline \hline No. & \multicolumn{1}{c}{ Quality Requirements } \\
\hline 1 & Game provides a clear goals \\
2 & Game is easy to understand \\
3 & Game can be played in a short time \\
4 & Game have complete features \\
5 & Control of the game has been consistently in according with the standards \\
6 & Screen layout is comfortable to be seen \\
7 & Audio of the game was comfortable and supportive with a good game \\
8 & The mobile device screen is appropriate to the game \\
9 & The experience of playing is Fun \\
10 & Storyline or scenario of the game is interesting \\
11 & No repetition that make the game boring \\
12 & Game control is appropriate and flexible \\
13 & Players gain knowledge from the game \\
14 & Game is simple but meaningful \\
15 & Content on tourism must be update \\
16 & Language usage appropriate to target of player \\
17 & Having educate messages behind the entertainment given \\
\hline \hline
\end{tabular}

\section{Conclusion and Future Works}

Based on the analysis and evaluation, the conclusions of this research are software quality requirements especially in the game are heavily dependent on type and case studies that will be develop. Software quality requirements can be composed of any various kinds of input, not only from the existing criteria, but also can be collected based on user feedback and the specific requirements of stakeholders that will use the software. Quality requirements for mobile educational game on tourism case studies has been built specifically based on the criteria that collected to build a good quality software. The proposed quality requirements can become a reference in building software educational game design since the beginning, so the quality of mobile educational games already maintained earlier.

For future research, the proposed quality requirements should be performed a validation testing on the feasibility, so that it can be more confirmed as good quality requirements. And the proposed quality requirement can be a reference to build a quality model with specific quality factors and complete metrics to evaluate the mobile educational game software, so it can measure how much the quality value of a mobile educational game in tourism theme.

\section{Acknowledgment}

We would like to thank to Politeknik Caltex Riau to Support this research, also to Riau Province and Pekanbaru City's Tourism Ambassadors "Bujang-Dara" to help us with very generous discussion and feedback.

\section{References}

[1] Clearwater, D. A. (2011). What defines video game genre? Thinking about genre study after the great divide. The Journal of the Canadian Game Studies Association, 5(8). 
[2] Trisnadoli, A., Hendradjaya, B., \& Danar, S. W. (2015). A proposal of quality model for mobile games. Proceedings of 2015 International Conference on Electrical Engineering and Informatics. IEEE.

[3] Trisnadoli, A. (2015). Software quality requirement analysist on mobile game based software (Analisis kebutuhan kualitas perangkat lunak pada software game berbasis mobile). Journal of Applied Computer (Jurnal Komputer Terapan), 1(2).

[4] Sánchez, J. G., Simarro, F. M., Zea, N. P., \& Vela, F. G. (2009). Playability as extension of quality in use in video games. Proceedings of 2nd International Workshop on the Interplay between Usability Evaluation and Software Development (I-USED).

[5] Ponnada, A., \& Kannan, A. (2012). Evaluation of mobile games using playability heuristics. Proceedings of the International Conference on Advances in Computing, Communications and Informatics (pp. 244-247). ACM.

[6] Hussain, A., \& Kutar, M. (2008). Usability metric framework for mobile phone application. Proceedings of the 10th Conference on Information Integration and Web-based Applications \& Services (pp. 567-570). ACM.

[7] Jeong, E. J., \& Kim., J. (2009). Definitions, key characteristics, and generations of mobile games. Mobile Computing: Concepts, Methodologies, Tools, and Applications. Monash University.

[8] Korhonen, H., \& Koivisto, E. (2006). Playability heuristic for mobile game. Proceedings of the 8th Conference on Human-Computer Interaction with Mobile Devices and Services (pp. 9-16). ACM.

[9] Nantes, A., Brown, R., \& Maire, F. (2008). A framework for the semi-automatic testing of video games. Proceedings of the Fourth Artificial Intelligence and Interactive Digital Entertainment Conference (pp.197-202).

[10] Nayebi, F., Desharnais, J. M., \& Abran, A. (2012). The state of the art of mobile application usability evaluation. Proceedings of 25th IEEE Canadian Conference on Electrical and Computer Engineering (pp. 1-4). IEEE.

[11] Salmre, I. (2005). Writing mobile code: Essential software engineering for building mobile applications. Addison-Wesley Professional.

[12] Sugihartono, Fathiyah, K. N., Setiawati, F. A., Harahap, F., \& Nurhayati, S. R. (2007). Psychology of Education (Psikologi Pendidikan). UNY Press.

[13] Handriyantini, E. (2009). Computer Based Educational games for Elementary Student (Permainan edukatif berbasis komputer untuk siswa sekolah dasar). Malang: Journal of STIKOM Indonesia (Jurnal STIKOM Indonesia).

[14] Harahap, Y. M. (2015). Design of Educational Game as a Learning Media for Preschool Children with Adobe Flash CS 5. SP (Perancangan Game Edukatif Sebagai Media Pembelajaran Pada Anak Usia Dini Dengan Adobe Flash CS 5. SP) - Mathematics, USU.

[15] Hurd, D., \& Jennings, E. (2009). Standardized educational games ratings: Suggested criteria. Scientific Paper.

[16] Dondlinger, M. J. (2007). Educational video game design: A review of the literature. Journal of applied educational technology, 4(1), 21-31.

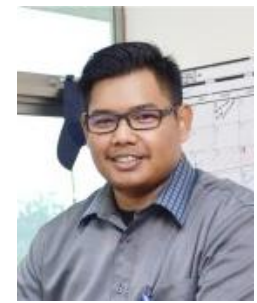

Anggy Trisnadoli obtained his B.Sc. degree in informatics engineering from Politeknik Caltex Riau in 2011, a M.Sc. also in informatics magister from Bandung Institute of Technology in 2015. He has worked as a lecturer in Politeknik Caltex Riau from 2012. Currently, he is lecturing in information system, Computer Department of Politeknik Caltex Riau, Indonesia. His research interests are in games, mobile application, 3D animation and multimedia software. 


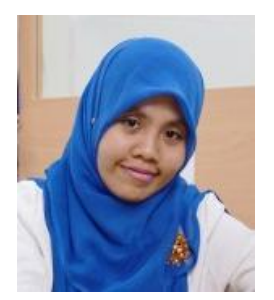

Istianah Muslim is a lecturer in Information System Department in Politeknik Caltex Riau. She received her master of industrial engineering from Institute of Technology Sepuluh Nopember in 2013. Her research interests are in the area of human factor, ergonomic, safety and health, supply chain management, production planning and Design Product.

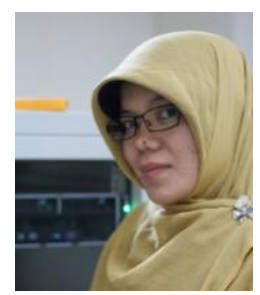

Wenda Novayani is a lecturer in Computer Engginering Department in Politeknik Caltex Riau. She received her diploma degree in computer engginering from Politeknik Caltex Riau in 2006 and a B.Sc degree in electrical engginering from Intitute Teknologi Bandung in 2013. HHer research interests are in mobile application, games, animation and geografic information system. 